DOI: https://doi.org/10.24297/jssr.v15i.8624

\title{
Reconstruction of Severance Pay and Workers' Rights Due to Termination of Employment (Layoff) Based on Justice Value
}

\author{
Rahmatsyah, Anis Mashdurohatun, Gunarto \\ ${ }^{1}$ Doctoral program of Law, Faculty of Law Unissula Semarang Indonesia \\ ${ }^{2,3}$ Faculty of Law Unissula Semarang Indonesia \\ anism@unissula.ac.id
}

\begin{abstract}
Employers have an interest in increasing the productivity of their business performance, whereas workers have an interest in obtaining wages, rewards or incentives from carrying out work. Employee relations with employers often occur disputes that end in Termination of Employment (layoff). The implementation of layoffs can lead to conflict if one party does not accept the dismissal decision. The settlement of the industrial relations dispute is generally settled using Law No. 13 of 2003 concerning Employment. But, in this law, there are still many weaknesses that can be distorted by and overlapping causes legal uncertainty inferred from Article 156 Paragraph (1). The purpose of this study is to carry out reconstruction in Article 156 Paragraph (1) to fulfill the element of justice for workers. This study use empirical juridical approach method related to the granting of workers' rights due to layoffs. The type of data used in this study includes primary data and secondary data. The collected data were analyzed by descriptive analytics. The results of the study found that giving of workers' severance and rights due to layoffs occurred injustice and disadvantaged the workers as weak party. This injustice can be in the form of non-payment of rights that should be received by workers due to layoff, legal uncertainty, and ambiguity in the judge's decision. Therefore, in order to guarantee legal certainty on the balance of rights and obligations for employers and workers, the legal norms reconstruction in Article 156 Paragraph (1) needs to be emphasized by adding the length of time of the given rights and the reasons for the layoff workers' rights.
\end{abstract}

Keywords: Justice, Termination of Employment, Workers' Rights.

\section{Introduction}

In the era of globalization ${ }^{1}$, all sectors of the economy have very tight competition because more and more competitors are in the same field. Philosophically, employers and workers have interests in accordance with their respective roles. Employers have an interest in improving the productivity of their business performance both in the field of goods or services, whereas workers have an interest in obtaining wages, rewards or incentives from carrying out work. Both parties, namely employers and workers, have a working relationship after the employment agreement. ${ }^{2}$ The relationship between employers and workers does not always run harmoniously,

${ }^{1}$ The influence of globalization in all areas such as in the social, economic, and culture increasingly driving the pace of economic development of society. See to Anis Mashdurohatun \& Gunarto, Comparison of Trademark Laws as Fiduciary Guarantee Objects, Advances in Social Science, Education and Humanities Research, volume 192. Published by Atlantis Press. Amsterdam, the Netherlands, 2018.p.188. see to I. Gusti Ayu Ketut Rachmi Handayani, Edi As'Adi, Guntur Hamzah, Tommy Leonard, Gunarto, Relationship between Energy Consumption in International Market and Indonesia Prices Regulation,International Journal of Energy Economics and Policy, 2017, 7(5), 9-15. And see to Anis Mashdurohatun, Gunarto \& Lathifah Hanim, The Urgency of Legal Protection to the Trademarks in the Global Era, Jurnal Pembaharuan Hukum, Volume V, Issue 3, September-Desember 2018, p.260.

2 According to Article 1 Paragraph (14) Law No 13 Year 2003 that states working agreement is an agreement between the workers/employees and the employers that contains terms, rights and obligations of the parties. 
but disputes can occur that end in Termination of Employment (Layoff). The implementation of layoffs can lead to conflict if one party does not accept the dismissal decision.

Law of the Republic of Indonesia Number 13 of 2003 concerning Manpower/Employment as a product of labor law explains that labor laws are formed as an effort to provide protection to workers and employers. Protection of workers is carried out by providing guarantees of workers' basic rights and guarantees equal opportunities and treatment without discrimination in any form for the welfare of workers / laborers and their families while taking into account developments in the progress of the business world. Protection of employers is done by protecting the rights of employers from fraudulent actions or unlawful behavior committed by workers.

In the case of layoffs in industrial relations regulated in Article 150 to Article 172 of Law No. 13 of 2003 concerning Manpower/Employment, including the reasons for layoffs. ${ }^{3}$ Termination of Employment does not mean resolving problems in the case of an employment agreement. Termination of employment often has another set of problems if one party feels aggrieved by the decision. The main factor that often becomes polemic and raises new problems is the problem of workers' severance pay. The issue of severance pay is often a problem because it relates to the sense of justice assessed by each party. In general, one party feels treated unfairly with another party. This is as the Supreme Court (Mahmakah Agung) Decision Number 755 K/Pdt.Sus-PHI/2017, Number 1/Pdt.Sus-PHI/2015/PN Plk, Number 1386 K/Pdt.Sus-PHI/2017, Number 534 K/Pdt.Sus-PHI/2015, and Number 836 K/Pdt.Sus/2011 namely the court's decision that determines severance severity is not in accordance with workers' expectations and employers' views. The sense of justice proposed by the employer is inversely proportional to the sense of justice expected by the worker. Employers generally want to give severance in less amount than the wishes of workers so that workers feel that the employer's treatment is unfair, especially if workers feel they have provided services to employers and have long years of service.

Another decision that raised issues regarding severance was Decision No. 110/Pdt.Sus-PHI.G/2017/PN.Jkt. Pst. In this ruling, there is controversy regarding severance pay, years of service appreciation money and money to substitute rights that were not paid by employers because of Law No. 13 of 2003 does not regulate the provisions of compensation that must be paid by employers against workers who were laid off for urgent reasons. In Law No. 13 of 2003 only regulates 1 (one) time compensation for layoffs in Article 156 Paragraph (2), reward for years of service in Article 156 Paragraph (3) and compensation money for rights in Article 156 Paragraph (4). By not regulating compensation for layoffs for urgent reasons, the rights of workers will be very weak and can be used as a reason for layoffs by employers.

In Decision No. 05/Pdt.Sus-PHI/2016/PN.Jkt.Pst and Decision No. 08/Pdt.Sus-PHI/2016/PN.Jkt.Pst, there is controversy regarding the provisions of Article 155 Paragraph (2) of Law No. 13 of 2003 that before the dismissal of the dispute was declared by the industrial relations court, both parties must carry out their rights and obligations. Based on the provisions of Article 155 Paragraph (2), the worker has an obligation to continue working in carrying out his duties as a worker, and the employer has the obligation to pay wages and other worker's rights before a court decision. This is stated in Article 155 Paragraph (3) that employers must pay wages during the layoff process. But on the other hand, Article 93 Paragraph (1) states that wages are not paid if workers do not do work. Article 93 Paragraph (1) is prone to irregularities, that is, employers prohibit workers from carrying out their obligations because there have been industrial relations conflicts between workers and employers. If the parties dispute with each other over the issue of layoffs, then workers can certainly be forced not to carry out their obligations to work. If the worker does not carry out his obligations or does not work, then the provisions in Article 93 Paragraph (1) that will be used by the judge in deciding the case that the worker does not carry out the obligation, then laid off with a decision that can harm the worker on the pretext the worker does not carry out the obligation.

On this issue, judges are required to have wisdom because the position of workers in industrial relations has a weak position, so that each decision given must provide benefits to the community, justice and legal certainty. Based on the phenomenon of the gap between das solen and das sein, further research needs to be done on

${ }^{3}$ Abdul R. Bodiono, 2009, Hukum Perburuhan, Jakarta: PT Indeks, p.79 
the legal protection of workers due to termination of employment, factors that affect the protection of workers 'law and protection of workers' law due to termination of employment based on fair value.

\section{Research Method}

This study use constructivism paradigm, that views the reality of social life is not a natural reality but is formed from the results of construction. In this study use the empirical juridical approach method related to the granting of workers' rights due to layoffs. The type of data used in this study include primary data and secondary data ${ }^{4}$. Primary data is data obtained directly from the object, while secondary data is data obtained from library materials. ${ }^{5}$ The method of analysis is descriptive analytical method. This method is based on the depth of collected data. The collected data will be sorted and described thoroughly, systematically, critically and constructively in the labor law system.

\section{Results and Discussion}

Justice is to ensure legal certainty, then justice is used as a middle theory in this study. This formulation of justice has two very basic opinions that need to be considered: First, the views or opinions of the laity which basically formulate what is meant by justice is the harmony between the use of rights and the implementation of obligations in line with the postulate of the legal balance namely the measure of rights and obligations. Second, the views of legal experts who formulate that justice is harmony between legal certainty and legal comparability. ${ }^{6}$ Based on the two views on justice, it can be seen that justice is the existence of harmony or congenial.

Aristotle distinguishes justice into distributive justice and commutative justice. Distributive justice is justice that demands that everyone gets what is rightfully theirs, so it is proportional. ${ }^{7}$ Commutative justice concerns the issue of determining fair rights among several equal personal human beings, both among physical and nonphysical personal persons. ${ }^{8}$ The existence of legal certainty is a hope for justice seekers of arbitrary actions by law enforcement officials who are sometimes too arrogant in carrying out their duties as law enforcers (applied theory).

In a country's legal system, Subekti states that the system is an orderly arrangement or order, a whole consisting of parts related to one another, arranged according to a plan or pattern, the result of writing to achieve a goal.

9 In a good system, there should not be a conflict between parts. Besides, duplications or overlaps between these parts may not occur. A system contains several principles that guide the formation. ${ }^{10}$

Indonesia is a country that adheres to the continental European legal system. The continental European legal system develops in mainland European countries and is often referred to as "Civil Law". ${ }^{11}$ The Civil Law system has three characteristics, namely the codification. The judge is not bound to the president so that the law becomes the main source of law, and the justice system is inquisitorial. The main characteristic that forms the basis of the Civil Law system is that the law obtains binding power because it is manifested in regulations in the form of laws and systematically arranged in the codification. This basic characteristic is held in view that the main value, which is the goal of the law is legal certainty. Legal certainty can only be realized if human legal actions in the association of life are regulated by written legal regulations. With the purpose of the law and based on the legal system adopted, judges cannot freely create laws that have a general binding force. The

\footnotetext{
${ }^{4}$ Anis Mashdurohatun, Said Gunawan \& Teguh Prasetyo, The Weaknesses of the Principle of Arrragement of Nonaluutsista ofthe Indonesian National Army, International Journal of Economic Research, Volume 14, Number 15, 2017. p.328.

5 Soerjono Soekanto,1982, Pengantar Penelitian Hukum, Penerbit Universitas Indonesia (UI-Press), Jakarta, p. 52

${ }^{6}$ A. Ridwan Halim, 2015, Pengantar Ilmu Hukum Dalam Tanya Jawab, Jakarta: Ghalia Indonesia, p.176.

7 J.H. Rapar, 2019, Filsafat Politik Plato, Jakarta: Rajawali Press, p. 82.

${ }^{8}$ Ibid.

${ }^{9}$ IInu Kencana Syafiie, 2003, Sistem Adminitrasi Negara Republik Indonesia (SANRI), Jakarta, Bumi Aksara, p. 2

10 Ibid.

11 Dedi Soemardi, 1997, Pengantar Hukum Indonesia, Jakarta, Indhillco, p.73
} 
judge only functions to set and interpret the rules within the limits of his authority. Decisions of a judge in a case only bind the parties to the case alone (Doktrins Res Ajudicata). ${ }^{12}$

According to Friedman, there are 3 (three) instruments for law enforcement, namely legal structure, a legal substance, and legal culture. ${ }^{13}$ In the context of this research concerning labor, the component of the legal structure is the existence of an institution as a concrete manifestation of the component of the legal structure. In this case, the existence of an institution that accommodates all labor components in Indonesia. This has been realized, namely the existence of the Department of Manpower in each district, even higher at the provincial level and highest at the central government. The institution conducts guidance and supervision as well as all matters of employment in Indonesia. Although in the area of supervision, there are still weaknesses due to lack of budget and the number of supervisors, the government has made an online surveillance effort initiated in 2019. In addition to the ministry of manpower and its derivatives at the lower level, the structure is also related to the existence of the structure of law enforcement institutions, namely the police, the administration, and the court. In the hands of law enforcers, labor law will be implemented. This has been realized with the existence of law enforcement institutions. The police, prosecution, and court consist of people who play an important role in terms of upholding the law. Thus the law enforcers must have wisdom, honesty, justice in terms of treating the parties in dispute.

The second component is the legal substance. Legal substances include written law and unwritten law. On the substance of this labor law, weaknesses still occur, namely, in terms of the content of labor regulations in force in Indonesia. An example is the substance of Law No. 13 of 2003 which still reaps injustice for workers as recorded in the Constitutional Court Decision No. 012 / PUU-I / 2003 Testing Law No. 13 of 2003 concerning Manpower Against the 1945 Constitution and has been published in State Gazette Number 92 of 2004 dated 17 November 2004. It is deemed necessary to issue a Circular of the Minister of Manpower and Transmigration of the Republic of Indonesia No. SE-13 / MEN / SJ-HK / I 2005 concerning Decision of the Constitutional Court Judicial Rights of Law No. 13 of 2003 concerning Labor Against the 1945 Constitution of the Republic of Indonesia. In the discussion about the Circular Letter mentioned above is the need to conduct a material test in Law No. 13 of 2003, especially in Article 158, Article 159, Article 160 Paragraph (1) insofar as it recognizes the clauses "... not on the complaints of employers", Article 170 as long as they know the clauses "... Article 158 Paragraph (1) ...", Article 171 as long as they know clause "... Article 158 Paragraph (1) ...", Article 186 insofar as it recognizes the clause "... Article 137 and Article 138 Paragraph (1) ..." does not have binding legal force.

The Circular Letter explained that the resolution of cases of layoffs due to workers making serious mistakes must pay attention to the following matters, namely employers who would make layoffs due to serious mistakes. Layoffs can be done after there is a decision of a criminal judge who has permanent legal force, and if the worker is detained by the authorities the provisions in Article 160 of Law No. 13 of 2003. If there is an urgent reason, which causes the employment relationship can not be resumed, the employer can make efforts to resolve through the industrial relations dispute resolution agency. Thus, the Circular Letter is very useful to protect the fate of workers from employer allegations that workers have made a grave mistake so that workers are terminated without terminating their rights in the form of severance pay, reimbursement rights, and years of service awards. The Circular Letter was also created to avoid ambiguity and legal uncertainty. In the opinion of researchers, in Article Law No. 13 of 2003, there are also still ambiguities that result in legal uncertainty, especially on the rules regarding termination. In addition to legal uncertainty, in the provisions of Law No. 13 of 2003, there is also an injustice that must get reconstructed to maintain the justice of every decision made by a judge. The legal uncertainty is in the following article.

\footnotetext{
12 Ibid.

${ }^{13}$ Friedman, Lawrence M. 1977. Law and Society An Introduction. New Jersey: Prentice Hall Inc.
} 


\section{a. Article 155 Paragraph (3) written as follows}

"Employers can deviate from the provisions referred to in paragraph (2) in the form of suspension for workers/laborers who are in the process of terminating their employment by still having to pay wages along with other rights commonly received by workers/laborers."

Article 155 Paragraph (3) contains uncertainty because if the employer wishes that the worker who was terminated does not carry out his obligation to work, then the employer can perform a suspension to the worker who is in the process of termination while still being obliged to pay wages along with other commonly accepted rights by workers. However, Article 155 Paragraph (3) does not mention how long the time limit is because it is known that the examination process until the decision to obtain legal force still requires a long time, can be estimated in a matter of months or years. If it is true that workers 'rights are given by the employer, doesn't the regulation harm the employer? Because the employer pays the worker without being matched by the employee's performance in the form of implementing obligations. However, if the employer does not grant the workers' rights, then this will affect the economic conditions of the workers disturbed because of the suspension. Furthermore, if the worker does not receive the results of the decision and will appeal, what about the system of rights granted to the worker while waiting for the worker to get a decision with permanent legal force. If workers repeatedly feel unwilling to accept the legal decision, then legal efforts can be pursued to the cassation level, and that would be very detrimental to both parties. On the other hand, if the suspension rules are enforced, the workers do not have peace of mind because they are related to the suspension period.

Article 155 Paragraph (3) also contradicts Article 93 Paragraph (1), which states that "Wages are not paid if workers do not do work." Article 93 does not regulate suspension as a form of exemption from payment of wages. Thus, the existence of no work no pay rules will be used as a basis for employers in conducting defaults on suspension actions committed by employers.

\section{b. Article 156 Paragraph (1), which is written as follows.}

In the event of a termination of employment, the employer is required to pay severance pay and/or work tenure awards and compensation payments that should be received.

In Article 156 Paragraph (1), it is written that if there is a termination of employment, without any exception being written, the judge must interpret for several things, for example, the following rights.

1) If there is a layoff done to workers who do not enter into work agreements with employers, whether they get the same treatment while the worker does not know his position and status at the company or not.

2) If there is a layoff, the employer serves a suspension to the workers that are not paid their rights up to the time of the trial process, whether there is compensation for the workers or not.

3) The absence of efforts to sanction criminal law for employers who default on the payment of rights granted to workers because of the payment of rights that are supposed to be done, but the default is certainly contrary to the values of human rights, religion and moral values living in the community.

Weaknesses in the substance of the law, as discussed at the point of legal certainty, also occur in legal justice. In the opinion of researchers, in Article Law No. 13 of 2003, there are still legal injustices, especially in the rules regarding layoffs. The legal injustice is in the following article.

Article 155 Paragraph (2), which is written as follows

As long as the decision of the industrial relations dispute resolution agency has not been established, both employers and workers must continue to carry out all their obligations.

Article 155 Paragraph (2) contains psychological injustice for workers because workers as parties who work, use labor, abilities, all their competencies for employers by working to expect wages/salaries from employers, then 
get mistrust again by employers so that layoffs are done to workers. Psychologically, working conditions and conditions are not conducive to both parties. Workers feel discomfort because their ability is doubted by the employer, and the employer feels that he no longer needs the competency of the employer. If the regulation stipulates that both parties continue to carry out their obligations as usual until the dismissal decision obtains permanent legal force, then this is very difficult for the worker to do. Shame, disappointment, and not accept the decision of layoffs definitely remain with the workers. On the other hand, employers who no longer need the competence of workers who are laid off will feel disturbed by the presence of workers who are not expected to return.

The substance of Article 155 Paragraph (2) is often still listed in the recommendation letter issued by the mediator, even though it is very difficult to implement due to psychological injustice for workers.

The existence of legal injustice contained in Article 155 Paragraph (2) is contrary to the legal objectives, as expressed by Gustav Radbruch ${ }^{14}$, that the main legal objective is legal justice. Article 155 Paragraph (2) also contradicts Aristotle's theory of distributive justice that justice is based on the number of services that have been performed. If viewed from the opinions of the two experts, Article 155 Paragraph (2) does not fulfill the element of psychological justice because the regulation will cause pressure, depression, shame, disappointment and discomfort for workers who have used all their energy for the company, but when the worker not being reused by termination of layoffs, the worker must be psychologically depressed in an uncomfortable situation to get the amount of salary/wage needed by the worker to support his living needs.

Psychological injustice is not judged as a hyperbolic thing or seems to be making it up, so that workers are more concerned and override the interests of employers. However, a comfortable atmosphere is also one of the 10 (ten) human rights that must be fulfilled, namely the right to a sense of security/comfort as contained in Law No. 39 of 1999 concerning Human Rights.

Researchers emphasize psychological justice because dismissal or termination in the form of layoffs has caused suffering for workers as parties who have no capital. Termination of Work Relations was never expected to occur by workers because workers need income or income, but because of limitations or mistakes made by workers, the workers are dismissed. Thus, if the rules give orders so that workers and employers continue to carry out the same obligations as long as the termination process has not been established or has not obtained permanent legal force, then workers will be more stressed by uncomfortable work situations.

The third component to ensure law enforcement is legal culture. Legal culture is an atmosphere of thought, social, and social forces that determines how the law is used, or in other words, the social atmosphere that lies behind people's attitudes towards law. ${ }^{15}$ In Indonesia, the most fundamental values and guidelines are the values found in Pancasila because these values are in accordance with the norms that exist in Indonesia. According to Hilman in Ismayawati ${ }^{16}$, legal culture is the same general response from certain communities towards legal phenomena. The response expressed by the community is a shared view of legal values and behavior. In that research, it was said that the Indonesian nation experienced legal degradation due to the weakness of legal awareness in the community so that many legal cases that harmed certain people did not get a good legal settlement. The lack of resolution is not due to the absence of rules, but the weak legal culture.

In the context of this study, the settlement of cases of disputes between workers and employers often results in injustice and disadvantages of the workers as weak parties. This injustice can be in the form of non-payment of rights that should be received by workers in the event of layoffs, no work agreements between workers and

14 G. Radbruch. Rechtsphilosophie in A. Kaufmann (ed) Gesamtausgabe vol 1 (Heidelberg: C. E. Müller Verlag. 1987). 97 [original $1^{\text {st }}$ edition: 8-9].

15 Friedman, Op.,Cit, p. 42

16 Any Ismayawati, Pengaruh Budaya Hukum Terhadap Pembangunan Hukum di Indonesia (Kritik Terhadap Lemahnya Budaya Hukum di Indonesia), Pranata Hukum, Volume 6 Nomor 1 January, 2011, pp. 55-68. 
employers, so that workers do not know their position and status in the company, and other losses. The adverse injustice does not get resistance from the community because the community has a weak position when faced with law enforcement officials. Thus, the injustice that causes harm only becomes a problem that has no solution. Values in life in society regarding the norm of employing a person are not detrimental to workers, both in terms of material and immaterial, because workers are employers' partners to be able to run businesses owned by employers. If this is ignored, then injustice will still be a problem for workers, and it will become a matter that is usually done by employers. This permissive attitude will then make the same view in society that workers have a weak position compared to employers as capital owners.

Legal use is one of the legal goals that must be achieved by law enforcement. The benefits provided in the form of decisions are not only useful for litigants but must be useful for the whole community.

The economic development and business competition are getting tougher and resulted in the emergence of various demands to be able to participate in the development of the economy. In connection with the increasing demands, the interests of each party are increasingly varied. Entrepreneurs who have capital with workers who need jobs and wages by offering their performance have different interests. Therefore to accommodate all existing interests, an employment agreement was made to avoid or minimize conflicts between employers and workers.

Work agreements arising from the two parties give rise to an employment relationship. However, the employment relationship between the two parties is not always smooth. However, the points in the work agreement have been formulated in such a way. There are still disputes caused by disputes due to differences in interpretation of rights, disputes of interest, disputes regarding the termination of employment, and disputes between workers or union's own workers. With the problems that can disrupt the wheels of the economy, then comes the effort to protect the rights of each party by using the rule of law.

There are various cases of layoffs that cannot be resolved through bipartite and tripartite channels, namely by involving a third party as a mediator, so many dismissal cases are brought into the realm of civil law. In the civil realm, layoffs are generally resolved using Law No. 13 of 2003 concerning manpower. In Law No. 13 of 2003 there are several articles governing layoffs, namely Article 150 to Article 172. In some of these articles, there is one article that is often used as a reference for judges when deciding cases, namely Article 156 Paragraph (1).

\section{Article 156 Paragraph (1) is written}

"In the event of a termination of employment, employers are required to pay severance pay and/or years of service awards and compensation money that should be received."

The sentence raises legal uncertainty because the entrepreneur is only required to pay severance pay, appreciation money, and compensation money, the amount of which is determined in the next paragraph. However, it does not regulate the reasons for layoffs and the length of time given. Therefore it can cause ambiguity or multiple interpretations from the judge when going to decide a case.

If the provisions are only written as in Article 156 Paragraph (1), then it can lead to several interpretations, which are as follows.

a. Every time a person is dismissed, the employer is obliged to pay severance pay, years of service awards, and compensation fees determined by the amount in the next paragraph. Thus, there are no exceptions to the reason for layoffs, but all layoffs will get the rights as referred to in Article 156 Paragraphs (2), (3), and (4).

b. There is no time limit for when the money will be paid, even though the layoff dispute settlement can take a long time to months. Thus it can cause ambiguity because the length of time is not determined and can be interpreted by the judge so that there is no legal certainty between case one and another case. 
Therefore, to fulfill the elements of legal certainty, justice, and reflected in legal actions, Article 156 Paragraph

(1) must be amended with the provisions of the following rules.

1) Every time a person is dismissed, the employer is obliged to pay severance pay, years of service awards, and compensation fees determined by the amount in the next paragraph. Thus, there are no exceptions to the reason for layoffs, but all layoffs will get the rights as referred to in Article 156 Paragraphs (2), (3), and (4).

2) There is no time limit for when the money will be paid, even though the layoff dispute settlement can take a long time to months. Thus it can cause ambiguity because the length of time is not determined and can be interpreted by the judge so that there is no legal certainty between case one and another case.

Therefore, to fulfill the elements of legal certainty, justice, and reflected in legal actions, Article 156 Paragraph (1) must be amended with the provisions of the following rules.

1) In the event of termination of employment, the employer is obliged to pay severance pay, and/or pay money for years of service and compensation money that should be received, except for termination of employment due to a serious mistake, only receive compensation, and/or a stipend specified in the employment agreement.

In writing like in the description above, it has more value of fairness and legal certainty because employers will not use the term other layoffs, except for layoffs for severe reasons. By using this word, there will be no layoffs due to urgent reasons as contained in the decision of No 110 / Pdt.sus-PHI.G / 2017 / PN. Jkt. Pst, namely the controversy regarding severance pay, the years of service appreciation money and money to replace rights that are not paid by employers because of Law No. 13 of 2003 does not regulate the provisions of compensation that must be paid by employers against workers who are laid off for urgent reasons. Law No. 13 of 2003 only regulates 1 (one) time compensation for layoffs in Article 156 Paragraph (2), the reward for years of service in Article 156 Paragraph (3), and compensation money for rights in Article 156 Paragraph (4). By not regulating compensation for layoffs for urgent reasons, the rights of workers will be fragile and can be used as a reason for layoffs by employers.

By reconstructing the sentence in Article 156 Paragraph (1) with more detail on the case of dismissal, it will minimize the occurrence of legal uncertainty when deciding on a case. The judge will not only state the urgent reasons for the dismissal and the rights to be received, but be more detailed in each case faced by each individual. Thus, decisions made by judges will be more useful, have legal certainty, and are just.

Severe mistakes are excluded from getting severance pay, and/or reward for years of service due to serious wrongdoing as provided for in Article 158 of Law No. 13 of 2003 also contradicts other laws, norms, and regulations. However, in order to reward employers for their service, workers who make a grave mistake may only receive compensation and /or separate money, which is generally determined separately (outside the labor law) in the employment agreement. However, in order to give compensation money and separation money must see the grave mistakes made by workers because it is also regulated in Article 160 of Law No. 13 of 2003.

2) In the case of industrial relations disputes and do not have permanent legal force, workers must carry out their obligations to work without obstruction from employers until a dispute with permanent legal force is decided.

3) In the case of an industrial relations dispute and does not yet have permanent legal force, the employer is obliged to give workers the right to work as usual and the rights of other workers until the dispute is decided by permanent legal force.

4) In the case of industrial relations disputes which do not have permanent legal force, the workers commit fraudulent acts or commit criminal acts to the detriment of other parties. Compensation rights will not be given to workers who have terminated employment but only given compensation money and separation money, which must also refer to Article 160. 
5) In the case of industrial relations disputes which do not have permanent legal force, the employer commits fraud or commits a criminal offense to the detriment of another party. The employer is obliged to give workers the rights of termination of employment twice as much as the provisions of Article 156 Paragraphs (2), (3), and (4).

The description above has more principles of justice and legal certainty because there will not be overlapping provisions as happened in Decision No. 05/Pdt.Sus-PHI/2016/PN.Jkt.Pst and Decision No. 08/Pdt.Sus PHI/2016/PN.Jkt.Pst, there is controversy regarding the provisions of Article 155 Paragraph (2) of Law No. 13 of 2003 that before the termination of a dispute is declared terminated by the industrial relations court, both parties are obliged to exercise their rights and obligations. Article 155 Paragraph (3) the employer must pay wages during the termination process. But on the other hand, Article 93 Paragraph (1) states that wages are not paid if workers do not do work. The two rules clash with each other because if the parties dispute with each other over the issue of layoffs, then workers can certainly be forced not to perform their obligations to work. Moreover, by not working, the provisions of Article 93 Paragraph (1) that will be used by judges in deciding cases. The provisions of the two articles should not conflict with each other.

The above description is more fulfilling the distributive justice side, and namely everyone gets what they are entitled to. ${ }^{17}$ Employees and employers are treated with proportional justice without taking sides. By fulfilling the element of justice, legal certainty will be easier to obtain by minimizing the arbitrary actions of law enforcement officials and cunning entrepreneurs. Legal certainty can only be realized if human legal actions in the association of life are regulated by written legal rules, in detail, and without ambiguity. With the purpose of the law and based on the legal system adopted, judges cannot freely create laws that have a general binding force. The judge only functions to set and interpret the rules within the limits of his authority. Decisions of a judge in a case only bind the parties to the case alone (Doktrins Res Ajudicata). ${ }^{18}$

The rules on layoffs as contained in Article 156 only regulates the obligation of employers to pay severance pay, years of service awards and compensation payments, but it is not discussed about employers' obligations when there are disputes in industrial relations between workers and employers, then by employers suspension, while waiting for a dispute to be tried until a decision with permanent legal force is obtained. In accordance with Article 155 Paragraph (3), this suspension action brings problems, namely cost, time, and time burden for both employers and workers.

The rules regarding suspension are only found in Article 155 Paragraph (3) without further explanation. Therefore suspension is often a new problem when the parties are still waiting for the first court decision. In accordance with Article 155 Paragraph (3), a suspension can be carried out with the obligation of the employer to continue to provide wages and other rights until a decision with permanent legal force is obtained. This is reinforced by Article 96 of Law No. 2 of 2004 concerning the Settlement of Industrial Relations Disputes that employers are required to pay wages and other rights as stated in Article 155 Paragraph (3) of Law No. 13 of 2003. If employers do not carry out this matter, then an interim decision can be given in the form of an order to pay wage rights and other rights to the employer, if the employer does not implement the matter, then the presiding judge may set a seizure guarantee.

The rules regarding the payment of the suspension period are used to protect workers, because there are many cases of irregularities committed by employers, namely doing a suspension without a time limit so that workers who will be harmed by the suspension are not limited to that time.

According to interviews with Pangkalan Bun District Court judges, layoffs are a common problem in the labor industry. The layoff was done because of the choice to solve the problem. Judges' response regarding the need for reconstruction Article 156 Paragraph (1) is a must to minimize the occurrence of legal uncertainty, especially relating to the acceptance of the rights of workers who have been laid off. Moreover, in the case of layoffs due to workers making grave mistakes in accordance with Article 158 of Law No. 13 of 2003, the treatment is given

${ }^{17}$ Loc.,Cit, J.H. Rapar, 2019

18 Loc.,Cit, Dedi Soemardi, 1997 
specifically regarding the rights received when workers were laid off was different, and should also refer to Article 160. However, according to Article 164 HIR, each party to the dispute must be able to prove and submit 5 (five) valid pieces of evidence, namely letters, witnesses, suspicion, confession, and oath. Thus, each party submits mutual evidence that can be justified. In the case of suspension, the judge also gave a statement that the suspension was often used as an excuse for the employer to lay off if the entrepreneur was not informed of clear rules regarding the employer's obligations when doing the suspension. In the case of suspension, no work, no salary applies, but the employer is obliged to commit to paying wages and other rights to workers. If the employer is not given such an obligation as stated in Article 155 Paragraph (3) and is clarified in Article 96 of Law No. 2/2004, then the employer will use the term to carry out unilateral layoffs that harm workers. In the case of suspension, there are specific steps taken for employers who do not fulfill the obligation to carry out payment of wages and other rights, namely confiscation of collateral. If the employer does not do that, the entrepreneur also violates the provisions of Article 374 of the Criminal Code, which reads:

"The embezzlement carried out by a person whose possession of the goods is caused by a working relationship or because of searching or because of getting a salary for it, is punishable by imprisonment for a maximum of five years."

In interviews with trade unions, it was said that the reconstruction in Article 156 Paragraph (1) was fundamental because the article was an article that was originally referenced when the employer intended to lay off. Therefore, the reconstruction of sentences in more detail will benefit the fate of workers who will be laid off by employers because workers as laypeople (do not understand the law in depth) can estimate or determine their fate when layoffs occur. What rights will be obtained and how much money will be received when the layoff. Laws or rules are made not only for legal experts but also for the public to avoid making sentences in ambiguous language that are confusing and cause misinterpretation so that it can lead to legal uncertainty. Workers are a weak party, so if there are problems with layoffs, workers must get protection from the rules. Therefore, if rules are not made in detail, they can lead to multiple interpretations that are detrimental to workers. In the case of suspension, this reason is often the reason when employers want to lay off workers. The suspension is carried out as an initial stage to lay off workers. Therefore, the suspension rules must be made clear, both the length of the suspension and the rights that can be received by the worker during the suspension period. In the case of suspension, the employer sometimes does not give workers rights because the worker does not perform work obligations as usual. If the guideline for providing basic worker rights payments used by employers is work obligations, then workers will not get any rights. This is as stated in Article 93, Paragraph (1) of Law No. 13 of 2003. In anticipating, the reconstruction of Article 156 Paragraph (1) must be explained that the suspension rules, especially in the case of payment of wages and workers' rights, are not treated equally with wage rules in general.

Minister of Manpower Decree No. KEP-150 / Men / 2000 concerning Settlement of Termination of Employment and Determination of Severance Pay, Period of Service Award and Compensation in Company (Kepmenakertrans No. KEP-150 / Men / 2000) provides an interpretation of the provisions of Article 155 paragraph (2) of Law No. 13 of 2003 which provides a process wage of only six months. Based on the provisions in Kepmenakertrans No. KEP-150 / Men / 2000 the number of fair process wages given based on justice is only six months of wages and not until a decision has final legal force. However, the Minister of Manpower Decree No. KEP-150 / Men / 2000 has a weakness because the court's ruling in Indonesia generally takes a long time, if the ruling is not yet available, and workers have been suspended all wages and rights, then the financial of workers who are in a suspension period will be disrupted. The practice of suspension by providing compensation for only up to 6 (six) months can result in unilateral and covert layoffs because, after six months, employers no longer have an obligation to provide wages and rights to workers. On the other hand, if the payment of wages and other workers' rights decides with a legal force still being issued, then it will be very detrimental to the employer because there is no contribution from the worker to the employer. Therefore, to guarantee the good faith of both parties, the suspension must have a maximum period of time that can be regulated by the government or arranged in an employment agreement at each company. 
Based on the results of the description above, Article 156 must discuss suspension, because suspension is very likely to be carried out by the employer. The provisions regarding suspension must explain the employer's obligation to pay wages and other workers' rights as well as the longest suspension period specified in the work agreement of each company.

Thus, Article 156 Paragraph (1) which initially only contained one sentence, then to guarantee the values of justice for employers and workers by guaranteeing the rights and obligations of employers and workers in a balanced manner, it is necessary to break down the layoffs' details into several numbers namely as follows.

1). In the case of termination of employment (layoff), the employer is obliged to pay severance pay, and / or pay money for years of service and compensation money that should be received, except for termination of employment due to a serious mistake, only receive compensation, and / or a stipend specified in the employment agreement.

2). In the case of industrial relations disputes and do not yet have permanent legal force, workers must carry out their obligations to work without obstruction from employers until a dispute with permanent legal force is decided.

3). In the event of an industrial relations dispute and does not yet have permanent legal force, the employer is obliged to give workers the right to work as usual and the rights of other workers until the dispute is decided by permanent legal force.

4). In the case of industrial relations disputes and do not yet have permanent legal force, if workers commit fraudulent acts or commit criminal acts to the detriment of other parties, then compensation rights will not be given to workers who have terminated employment, but only given compensation money and separation money which must also refer to Article 160 .

5). In the case of industrial relations disputes and do not yet have permanent legal force, if the employer commits fraud or commits a criminal offense to the detriment of another party, then the employer is obliged to give workers the rights of termination of employment twice as much as the provisions of Article 156 Paragraphs (2), (3) and (4).

6). In the event of a suspension, the employer is obliged to pay wages and workers' rights during the suspension period for the longest period stipulated in the work agreement.

\section{Conclusion}

Employers have not fulfilled justice in granting severance and workers' rights due to layoffs because workers have a lower bargaining value than employers and there are rules distorted by employers. By the absence of the the strong law to provide protection to workers, the position and bargaining value of workers becomes weaker. Factors that cause weaknesses of injustice in granting severance and workers' rights system due to layoffs by employers are, in law substance of Article 155 and Article 156, the position of workers is very weak, no employment agreement based on the legal structure, and lack of supervision from the government. Reconstruction of severance pay and labor rights based on justice value is legally guaranteeing the balance of rights and obligations for employers and workers, by reconstructing the legal norms of Article 156 Paragraph (1) of Law Number 13 year 2003 concerning Employment.

\section{References}

1. Abdul R. Bodiono, 2009, Hukum Perburuhan, Jakarta.

2. Anis Mashdurohatun \& Gunarto, Comparison of Trademark Laws as Fiduciary Guarantee Objects, Advances in Social Science, Education and Humanities Research, volume 192. Published by Atlantis Press. Amsterdam, the Netherlands,2018.

3. Anis Mashdurohatun, Said Gunawan \& Teguh Prasetyo, The Weaknesses of the Principle of Arrragement of Non-aluutsista ofthe Indonesian National Army, International Journal of Economic Research, Volume 14, Number 15, 2017. 
4. Anis Mashdurohatun, Gunarto \& Lathifah Hanim, The Urgency of Legal Protection to the Trademarks in the Global Era, Jurnal Pembaharuan Hukum, Volume V, Issue 3, September - Desember 2018.

5. Any Ismayawati, Pengaruh Budaya Hukum Terhadap Pembangunan Hukum di Indonesia (Kritik Terhadap Lemahnya Budaya Hukum di Indonesia), Pranata Hukum, Volume 6 Nomor 1 Januari, 2011.

6. Central Jakarta District Court Decision No.08/Pdt.Sus-PHI/2016/PN.Jkt.Pst

7. Central Jakarta District Court Decision No.110/Pdt.sus-PHI.G/2017/PN.Jkt.Pst

8. Central Jakarta District Court Decision No.05/Pdt.Sus-PHI/2016/PN.Jkt.Pst

9. Decision of the Supreme Court Number.836 K/Pdt.Sus/2011.

10. Dedi Soemardi, 1997, Pengantar Hukum Indonesia, Jakarta, Indhillco.

11. Friedman, Lawrence M. 1977. Law And Society An Introduction. New Jersey: Prentice Hall Inc.

12. G. Radbruch. Rechtsphilosophie in A. Kaufmann (ed) Gesamtausgabe vol 1 (Heidelberg: C. E. Müller Verlag. 1987). 97 [original $1^{\text {st }}$ edition: 8-9].Inu Kencana Syafiie, 2003, Sistem Adminitrasi Negara Republik Indonesia (SANRI), Jakarta, Bumi Aksara.

13. Gusti Ayu Ketut Rachmi Handayani, Edi As'Adi, Guntur Hamzah, Tommy Leonard, Gunarto, Relationship between Energy Consumption in International Market and Indonesia Prices Regulation,International Journal of Energy Economics and Policy, 2017

14. J.H. Rapar, 2019, Filsafat Politik Plato, Jakarta: Rajawali Press.

15. Law Number 13 of 2003 concerning employment

16. Law Number 2 of 2004 concerning Settlement of Industrial Relations Disputes

17. Minister of Manpower Decree No. KEP-150 / Men / 2000 concerning Settlement of Termination of Employment and Determination of Severance Pay, Period of Service Award and Compensation in Company.

18. Palangkaraya District Court Decision Number. 1 / Pdt.Sus-PHI / 2015 / PN Plk

19. Ridwan Halim, 2015, Pengantar Ilmu Hukum Dalam Tanya Jawab, Ghalia Indonesia, Jakarta.

20. Soerjono Soekanto,1982, Pengantar Penelitian Hukum, Penerbit Universitas Indonesia (UI-Press), Jakarta.

21. Supreme Court's Decision Number. 1386 K / Pdt.Sus -PHI / 2017

22. Supreme Court's Decision Number. 534 K / Pdt.Sus-PHI / 2015,

23. Supreme Court's Decision Number. 755 K / Pdt.Sus-PHI / 2017 